\title{
Analytical investigation of the feather decoration technique of a seventeenth to eighteenth century Chinese imperial hanging screen
}

\author{
An Gu ${ }^{1,2^{*}} \mathbb{D}$, Na Wang ${ }^{1,2}$, Yan-ju Kong ${ }^{1}$, Jia-yu Hou' ${ }^{1}$, Gen Li ${ }^{1,2}$ and Yong Lei ${ }^{1,2}$
}

\begin{abstract}
Decoration with feathers is a universal phenomenon in human history. Objects decorated with feathers were regarded as fine artworks and hence were enormously prized. In ancient China, dotting a surface with blue kingfisher feathers was a famous, complex and delicate decoration technique called diancui. Although various ancient diancui artworks appear in many museums around the world and researchers have realized significant results in studies of the history, technique and conservation of diancui, some key historical details are still not clear. In this research performed during restoration, an important object from the Palace Museum, the "Feather Decoration Hanging Screen with Birds and Flowers Pattern", was analyzed by various scientific technologies. This object is a Chinese imperial artwork of the Qing dynasty (seventeenth to eighteenth century) decorated with kingfisher feathers and the feathers of several other birds, and it represents the highest level of this period. As a typical and valuable case, the results provide important clues for solving questions arising from related academic fields.
\end{abstract}

Keywords: Feather decoration, Featherwork, Feather art, Diancui, China, Imperial, Qing dynasty

\section{Introduction}

Decoration with feathers is a universal phenomenon in human history. It was widely used in textiles, jewelry and painting in ancient America, Europe and China. At that time, objects decorated with feathers were regarded as fine art works and hence were enormously prized. [1-4] In ancient China, kingfisher feathers, with bright, mellow and constant blue or violet colors, were considered one of the best materials among various bird feathers for luxury decoration. Dotting a surface with kingfisher feathers was called diancui (tian-tsui or 点翠), which is a major traditional feather decoration technique in China. This technique can be traced back to the Warring States

\footnotetext{
*Correspondence: gu.an@outlook.com

${ }^{1}$ Department of Conservation Science and Technology, The Palace

Museum, 4 Jingshan Qianjie, Beijing 100009, China

Full list of author information is available at the end of the article
}

Period (475-221 BCE) [5] and became very popular in the Tang and Song dynasties (618-1279). The development of diancui reached its height in the Ming and Qing dynasties (1368-1912).

The diancui technique was complex and delicate. Craftsman pasted micron-sized feather fibers on a support and adjusted the microscopic structure and materials with subtle skills to obtain various textural and color effects. This demonstrated a high level of artistic achievement. Due to the rarity of kingfisher feathers, objects with diancui have always been deluxe artworks from ancient China and now appear in many museum and private collections around the world [6-9].

Although featherwork has recently been the subject of academic attention, research on this important Chinese tradition is comparatively sparse. Although some studies have led to significant results related to the history, technique and conservation of diancui $[4,5,7,10]$, some key
Springer Open

(c) The Author(s) 2021. This article is licensed under a Creative Commons Attribution 4.0 International License, which permits use, sharing, adaptation, distribution and reproduction in any medium or format, as long as you give appropriate credit to the original author(s) and the source, provide a link to the Creative Commons licence, and indicate if changes were made. The images or other third party material in this article are included in the article's Creative Commons licence, unless indicated otherwise in a credit line to the material. If material is not included in the article's Creative Commons licence and your intended use is not permitted by statutory regulation or exceeds the permitted use, you will need to obtain permission directly from the copyright holder. To view a copy of this licence, visit http://creativeco mmons.org/licenses/by/4.0/. The Creative Commons Public Domain Dedication waiver (http://creativecommons.org/publicdomain/ zero/1.0/) applies to the data made available in this article, unless otherwise stated in a credit line to the data. 
historical details are still not clear, especially the details of the complex technique. For example, (1) although only two kinds of kingfisher feathers (blue and violet) were used in diancui, obviously the ancient craftsman could slightly adjust the color and texture of the finishing surface to achieve a rich and vivid decorative effect. What skills did they use? (2) What materials and techniques were used in the supports and adhesives of diancui objects? These lie under the feather layer and are difficult to observe directly. (3) On some ornately decorated objects, both diancui and other kinds of feathers with different colors were used in different areas to enrich colors and patterns. What other feathers were used? Was the technique the same as that used with kingfisher feathers?

Analytical investigations of typical ancient diancui objects could be the most effective way to answer these questions. However, existing diancui objects are normally rare and precious because they are fragile and hard to preserve. The lack of samples has limited research in this field. The Palace Museum of China contains abundant diancui artworks from the Ming and Qing dynasties. In research performed during restoration, an important object in the collection of the Palace Museum, the "Feather Decoration Hanging Screen with Birds and Flowers Pattern", was extensively analyzed with various scientific technologies. This object is an imperial artwork of the Qing dynasty (seventeenth to eighteenth century); it was decorated with kingfisher feathers and feathers of several other birds, and it represents the highest level of technique for this period. With this typical and valuable example, the results provide important clues for addressing the questions mentioned above.

\section{Materials and experiments The hanging screen}

The hanging screen investigated in this study is part of the collection of the Palace Museum China, named the "Feather Decoration Hanging Screen with Birds and Flowers Pattern". It is thought that the hanging screen was made for the emperor in the Qing Dynasty (seventeenth to eighteenth century). However, the exact production date is unknown.

Normally, the diancui technique was used to make small objects (for example, jewelry) because of the rarity of the material and the difficulty of the process. However, this hanging screen is not only large (width $795 \mathrm{~mm}$ and height $1130 \mathrm{~mm}$ ) but also has an ingenious design and exquisite craft, and it reached the highest level of imperial diancui artworks in ancient China.

As shown in Fig. 1, the pattern of the screen is that of two birds standing on two stones with a background of trees, flowers and ground. Four kinds of feathers were used in the screen: the bird's body, leaves and flowers were made of light blue feathers; the stones and some parts of the birds were made of violet feathers; the tree trunk was made of brown feathers; the ground was made of dark irisated feathers and has been considerably eaten by insects.

\section{Samples}

Most parts of the screen were in good condition. Therefore, only nondestructive analysis without sampling was acceptable. However, a small leaf part dropped from the screen (Fig. 2) could be used for microsampling before it was restored and reattached. In addition, a small fragment from the ground area could be used for cross section analysis. Modern kingfisher feathers were also compared with feathers from the screen.

\section{Experiments}

Various microscopes were used to observe micromorphologies. A video microscope (LEICA DVM5000) with a $700 \times$ objective lens and a cross cantilever was used for in situ observation. A metallographic microscope (LEICA) with a spectrograph was used to observe the cross section and collect the visible spectrum (wavelength $360-1100 \mathrm{~nm}$ ) of the micro area of the feather. A biological microscope (Olympus) was used to analyze paper-based fibers dyed with Herzberg reagent. SEM (FEI Quanta600) with EDS (EDAX Genesis) was used for elemental imaging of the cross section. A FESEM (Tescan mira3) was used to observe the nanocoloration structure of kingfisher feathers.

FTIR, Raman, XRF and XRD spectroscopy technologies were used for analyses of materials. An FTIR microscope (Thermo Scientific Nicolet iN10) fitted with a mercury-cadmium-telluride detector cooled by liquid nitrogen was used for FTIR spectroscopy in the range $4000-675 \mathrm{~cm}^{-1}$ with a spectral resolution of $4 \mathrm{~cm}^{-1}$. Microsamples were laid on a microdiamond cell, and spectra were collected with the transmission mode of the FTIR microscope. Raman spectroscopy (RENISHAW Invia) was performed with a 50X objective lens (Olympus), $633 \mathrm{~nm}$ wavelength laser, $5 \mathrm{~mW}$ energy, $10 \mathrm{~s}$ exposure time, and a single integral. An M-XRF (Bruker M4 Tornado) spectrometer with a Rh X-ray source was operated at $50 \mathrm{kV}$ and $200 \mu \mathrm{A}$ with a beam size of $20 \mu \mathrm{m}$ and test time of $120 \mathrm{~s}$. XRD (Rigaku 2550/PC) studies were performed at $40 \mathrm{kV}$ and $150 \mathrm{~mA}$, scanning speed $=5$ degrees $/ \mathrm{min}$, step $=0.02$ degrees, $\mathrm{DS}=\mathrm{SS}=1$ degree, and $\mathrm{RS}=0.3 \mathrm{~mm}$.

There are a variety of methods for feather identification, such as classical taxonomy, microscopy with statistics, and molecular biology [11-13]. In this case, the feathers are fragments but not complete, so the classical taxonomy method was inapplicable. Molecular biology 

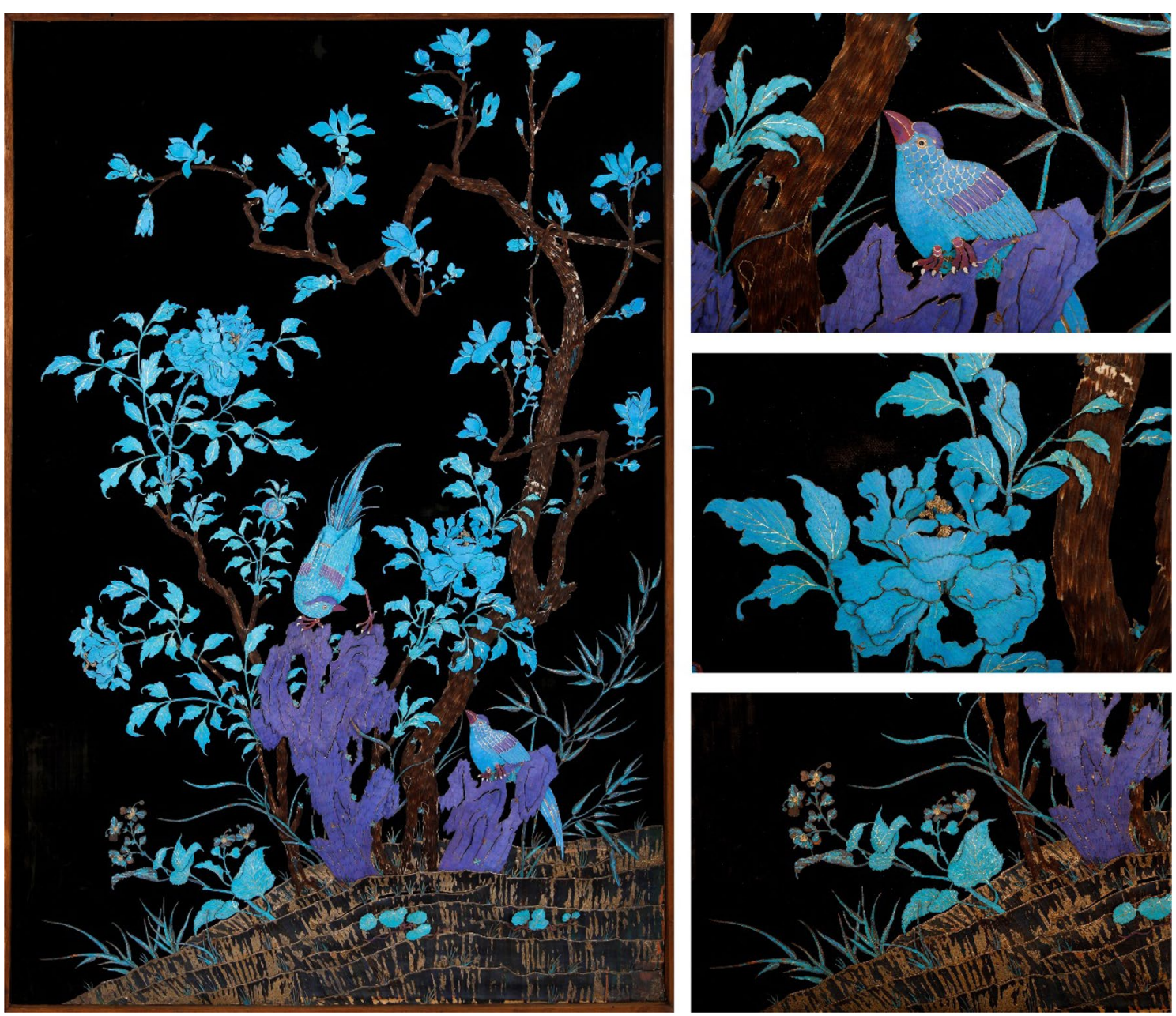

Fig. 1 Feather Decoration Hanging Screen with Birds and Flowers Pattern

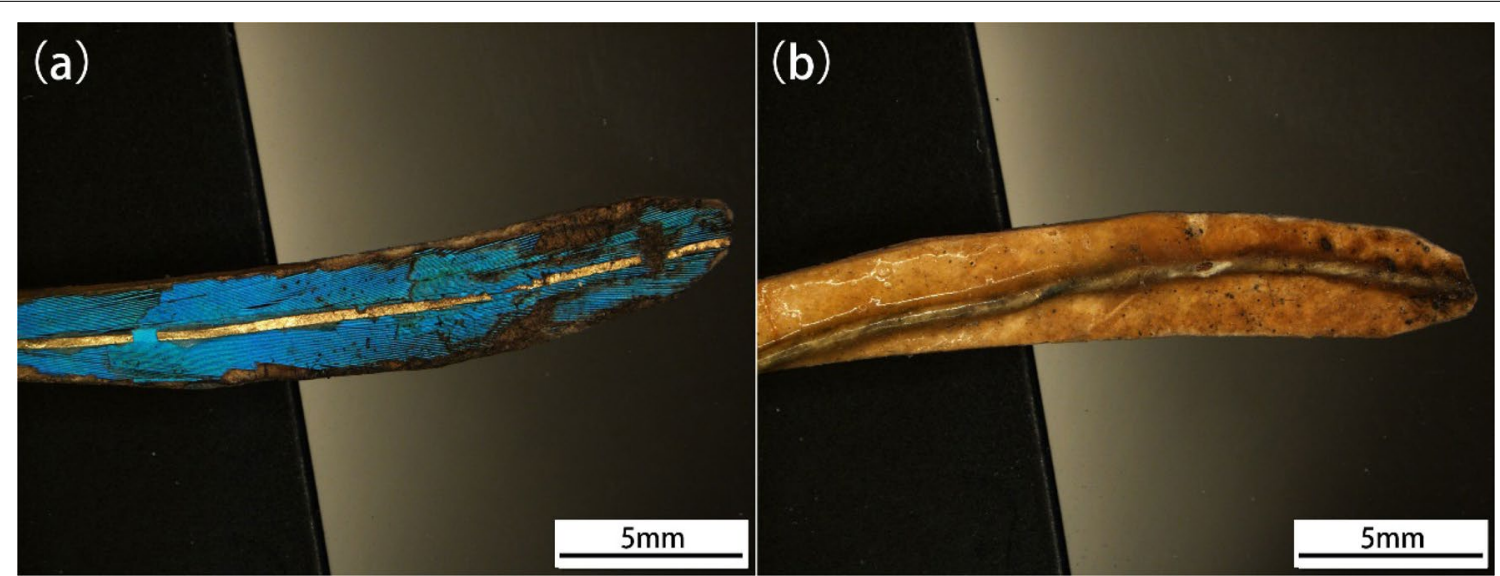

Fig. 2 A small leaf part that had dropped from the screen. a Front side. $\mathbf{b}$ Back side 
methods require sampling, which limits their application. Therefore, microscopic features of the feathers were compared with those in the literature and standard samples for identification.

\section{Results and discussion}

In this investigation, the details of the materials and techniques used for this hanging screen became clear. Four kinds of feathers were used in this screen. Microscopic identification showed that the light blue and violet areas were both made of kingfisher feathers. The color is a constant unordered structural color but is not dyed. Peacock feather was used in the ground area. The feathers of tree trunk areas are a variety of down feathers. To date, there are no accurate results because sampling is not allowed.

The structure of this diancui contains mainly of three kinds of layers: feather layer, glue and color layers and support body. The feather layer is on the surface. The base body is the supporting structure and is made of bamboo paper. Protein material was used for bonding paper together and sealing the back of the support body. A copper stick was sandwiched in the paper layers to strengthen the body. The glue and color layers have two functions. One involves bonding the feather fibers and the base body together. The other involves adjusting the sensorial color and texture. Light blue feathers were always used together with a black background color. Violet feathers were always used together with a red background color.

In addition to kingfisher feathers, peacock feathers were used to decorate the ground areas of the screen. The main structure of this area is similar to that of the diancui area. The difference is mainly in the background color layer. In this area, silver foil was used for background. The feather was pasted on the silver foil with yellow transparent protein glue, which made the foil look like gold. In addition, changing the gap between feather fibers could be used to fine tune the macroscopic color, which has also been documented by Paulson and Chase and McCarthy [7].

The majority of surviving diancui pieces are jewelry, in which the feathers are normally tightly packed. However, in this screen, the feathers are not tightly packed but spread out against a colored background, creating a variety of iridescent effects depending on density and coloration. This is most fascinating because in many discussions of featherworking, it is normally stated that South American traditions are the most complex, given that they used feathers from many different birds to create extremely complicated mosaics with delicate shading. It appears that on larger pieces, Chinese artists and artisans were attempting complicated color effects using background color, on which the kingfisher feathers were "dotted" or "spread" with a greater or lesser density. This means that we can consider jewelry as an outlier in diancui work. It is larger objects like this screen that show the "dotting" technique at its best.

Detailed data and discussion are presented below.

\section{Light blue area}

Light blue feathers were the most commonly used material in diancui. Fortunately, the dropped leaf part from the screen was light blue and could be analyzed entirely. As shown by the damaged part (Fig. 3a, c) and flank side (Fig. 3b), there are 6 layers in this part, as shown in Fig. 3d. The results of analytical investigations are shown for every layer in Table 1.

Table 1 Results of analytical investigations for every layer of the light blue area

\begin{tabular}{|c|c|c|c|}
\hline Layer name & Color & Material & Function \\
\hline Decoration Line & Golden & Gold & Delineate leaf veins \\
\hline Layer 1: feather layer & Blue & Kingfisher feathers & The main decoration surfaces \\
\hline Layer 2: back side glue layer & Black & Protein glue and carbon black & $\begin{array}{l}\text { The main function of this layer was to bond feather fibers } \\
\text { together to a feather sheet so that cutting and pasting } \\
\text { of small feathers would be much easier. In this case, this } \\
\text { layer was not transparent, but black. Thus, it was not only } \\
\text { for bonding but also served as another background color } \\
\text { layer in addition to Layer } 4\end{array}$ \\
\hline Layer 3: bonding layer & Transparent and yellow & Protein glue & Bonding of the feather sheet and support body together \\
\hline Layer 4: background color layer & Red & Protein glue and ochre & $\begin{array}{l}\text { Red layer on the top of the support body. The color can be } \\
\text { seen through gaps between feather fibers. It was used } \\
\text { along with layer } 2 \text { to affect the sensorial color and texture } \\
\text { of the surface }\end{array}$ \\
\hline Layer 5: support body & Pale yellow & Bamboo paper & Main part of the support body \\
\hline Skeleton & Brown & Copper & $\begin{array}{l}\text { Sandwiched in the paper layers to make the support body } \\
\text { stronger }\end{array}$ \\
\hline Layer 6: bonding layer & Transparent and yellow & Protein glue & Bonding this diancui component on the screen \\
\hline
\end{tabular}



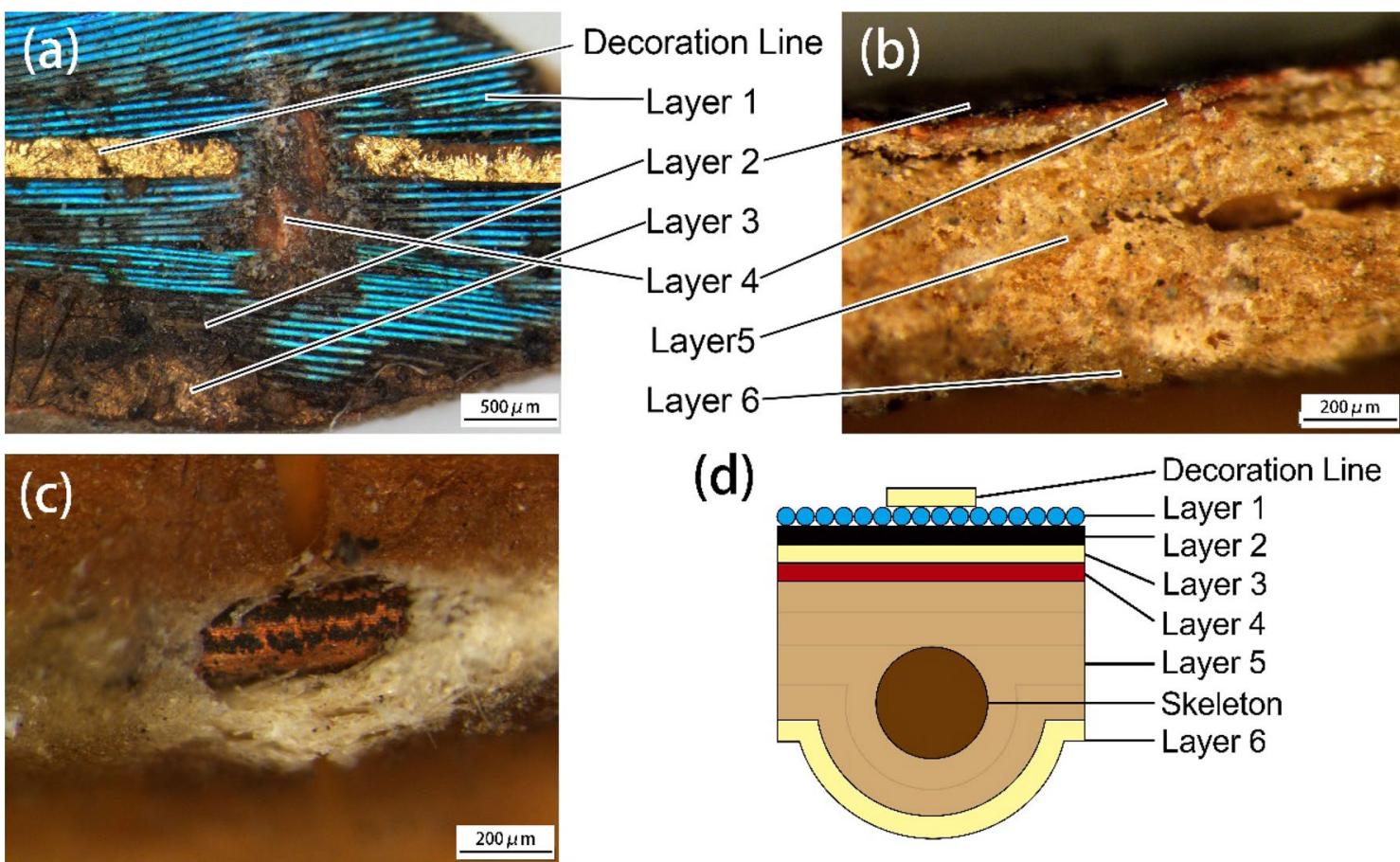

Fig. 3 Layer structure of the small leaf part (LEICA DVM5000 microscope). a Damaged part on the front side. b Flank side. c Exposed skeleton on the back side. $\mathbf{d}$ Structure sketches of layers. The results from investigation of every layer can be found in Table 1

According to this investigation on modern diancui craftsmen, a rough outline of the diancui process can be proposed. First, the feather back side was put up on a panel. Then, glue was brushed on the back side of the feather. Finally, the feather was separated from the panel by a knife as a feather sheet when the glue dried. This process protected the feather fibers from scattering and made them easier to cut to the required shape. Then, the feather sheets were glued on a support body. The analytical results for this screen fit this rough description of the process well, but more details were found. The following section contains detailed analytical results and discussion:

Layer 1: Layer 1 is the surface feather layer. It is obvious that this layer was spliced together with small pieces of feather because the seams could be found through microscopy (Fig. 3a). There is a golden line decoration on Layer 1. According to XRF results (Fig. 4a), the main element of this line is $\mathrm{Au}$, and it also contains small amounts of silver. The XRF signals for $\mathrm{Fe}, \mathrm{Ga}, \mathrm{Si}, \mathrm{K}, \mathrm{Sr}$ and $\mathrm{Zr}$ may be from layers under the golden line because they can also be found in the feather area. To identify whether the feather is from a kingfisher, microscopic methods were used to compare them with examples from the literature and with modern kingfisher feathers. Results showed that they matched well.
Using a stereomicroscope (Fig. 5a), it was observed that the diameters of the barbs are approximately $40 \mu \mathrm{m}$, and the barbules are short and not obvious from the dorsal side. The FESEM image shows that the barbs were composed of a keratin cortex and sponge matrix. The size of the keratin rods is approximately $70-100 \mathrm{~nm}$, and the size of the air spaces between the keratin rods is approximately $100 \mathrm{~nm}$ (Fig. 6a). These features fit the back feather of kingfisher well according to the literature [14] and the modern kingfisher feather (Figs. $5 \mathrm{~b}$ and $6 \mathrm{~b}$ ).

In addition, the color of kingfisher feathers is a structural color formed by interference, diffraction and scattering of light by the nanostructure of feathers [15]. This is why the color of diancui is constant. Infiltration by liquid with a high refractive index is a simple method of verifying structural color [16]. As shown in Fig. 7a, b, some parts of the screen feather gave rise to a transparent brown color, and the visible spectrum redshifted (Fig. 7c) after infiltration by isoamylol (refractive index $=1.4$ ). When the isoamylol volatilized, the color returned to blue. This phenomenon showed that the feathers had structural color and were not dyed.

Layer 2: Normally, this layer was a kind of glue that was painted on the back sides of feathers to bond the feather fibers to a feather sheet so that cutting and pasting would be much easier. Normally this layer is called the "back side glue layer". The microsample of this layer was tested 

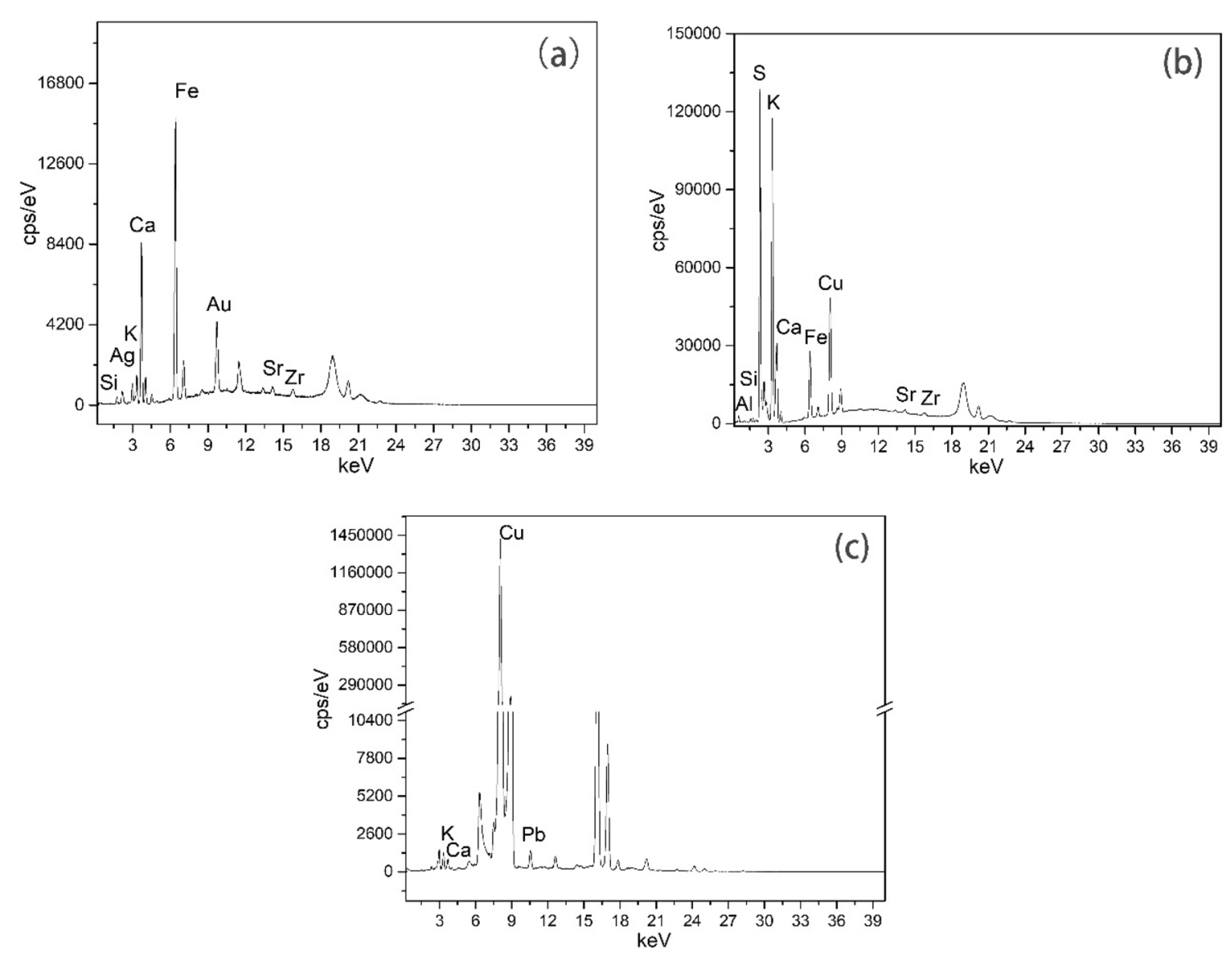

Fig. 4 XRF spectra of the golden line (a), feather area (b) and stick in layer 5 (c)

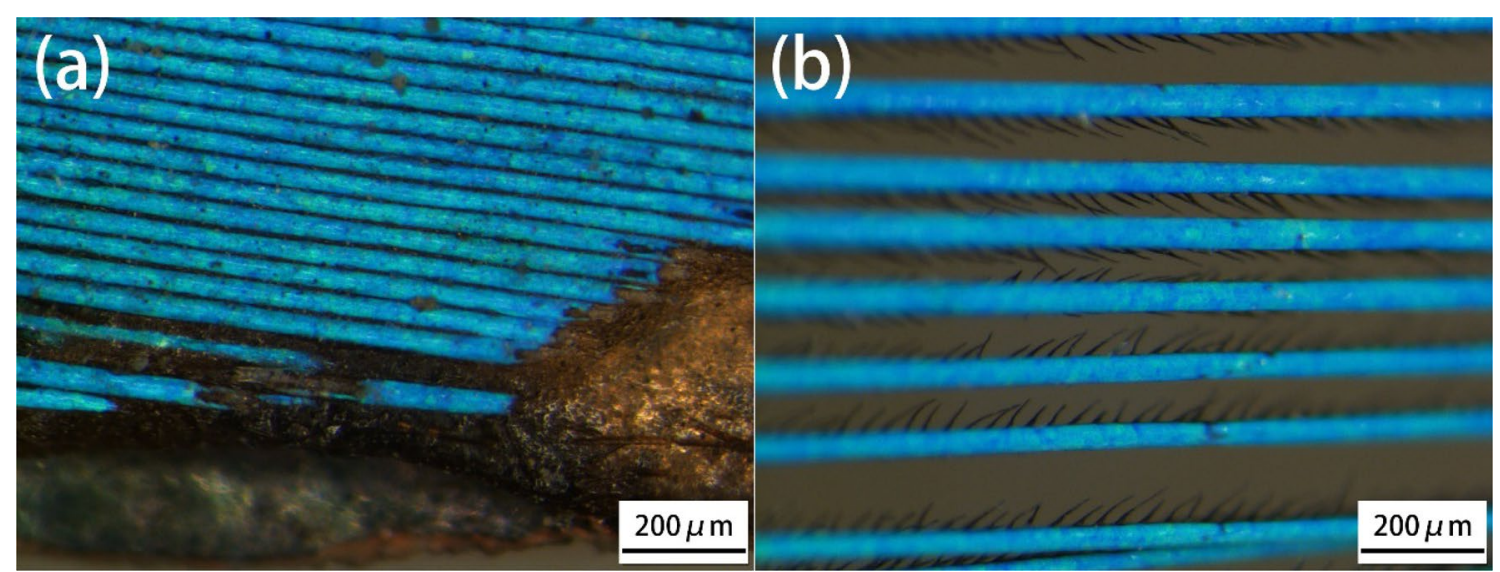

Fig. 5 Comparison of the feather from the screen (a) with a modern kingfisher feather (b) (LEICA DVM5000 microscope)

by microscopic FTIR. The result (Fig. 8a) shows that the glue material is protein, according to bands at $1650 \mathrm{~cm}^{-1}$ ( $\mathrm{C}=\mathrm{O}$ stretching band), $1550 \mathrm{~cm}^{-1}(\mathrm{C}-\mathrm{N}-\mathrm{H}$ bending band), $1450 \mathrm{~cm}^{-1}$ (CH bending band) and $3350 \mathrm{~cm}^{-1}$
(N-H stretching band) in the spectrum. The bands of $1140-1080 \mathrm{~cm}^{-1}$ and $990 \mathrm{~cm}^{-1}$ should be the asymmetric and symmetric stretching bands of $\mathrm{SO}_{4}{ }^{-2}$. [17] The $\mathrm{XRD}$ result (Fig. 9) showed that syngenite is contained in 


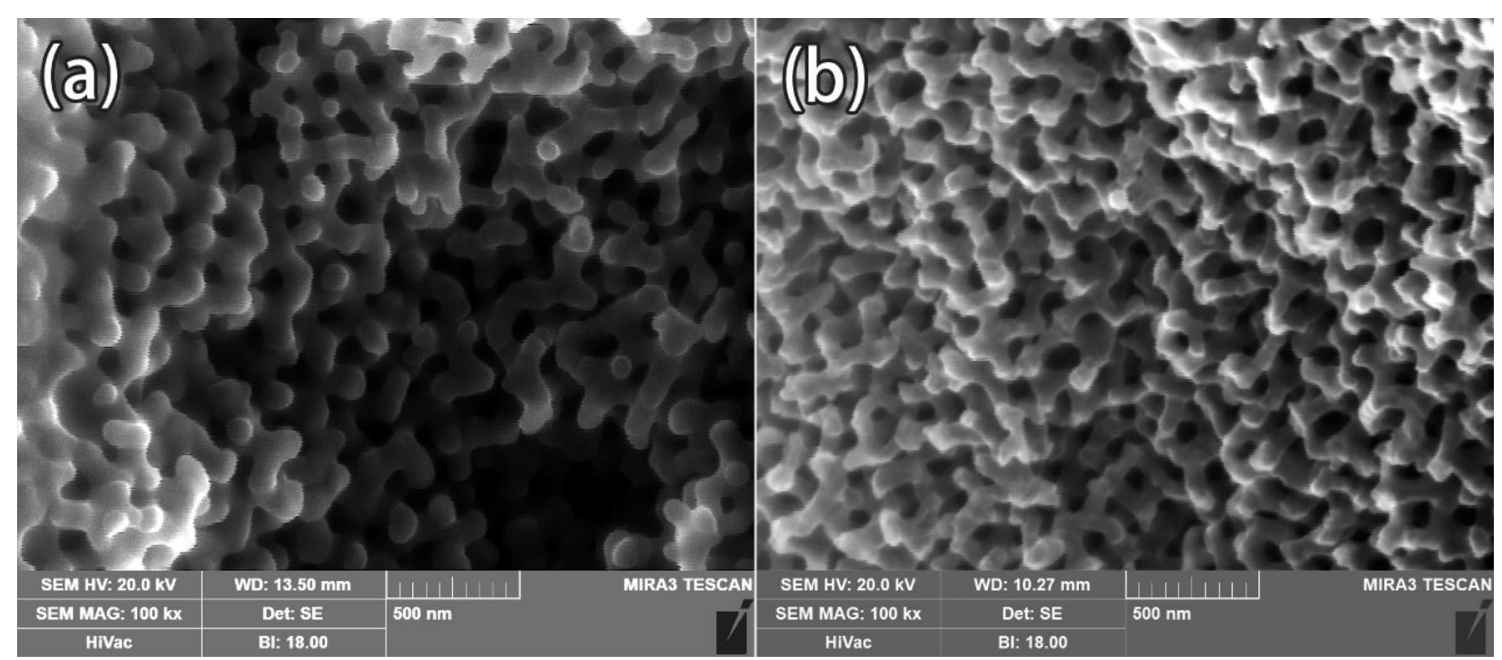

Fig. 6 Nanostructure of the ancient feather (a) and the modern kingfisher feather (b) (Tescan mira3 SEM)
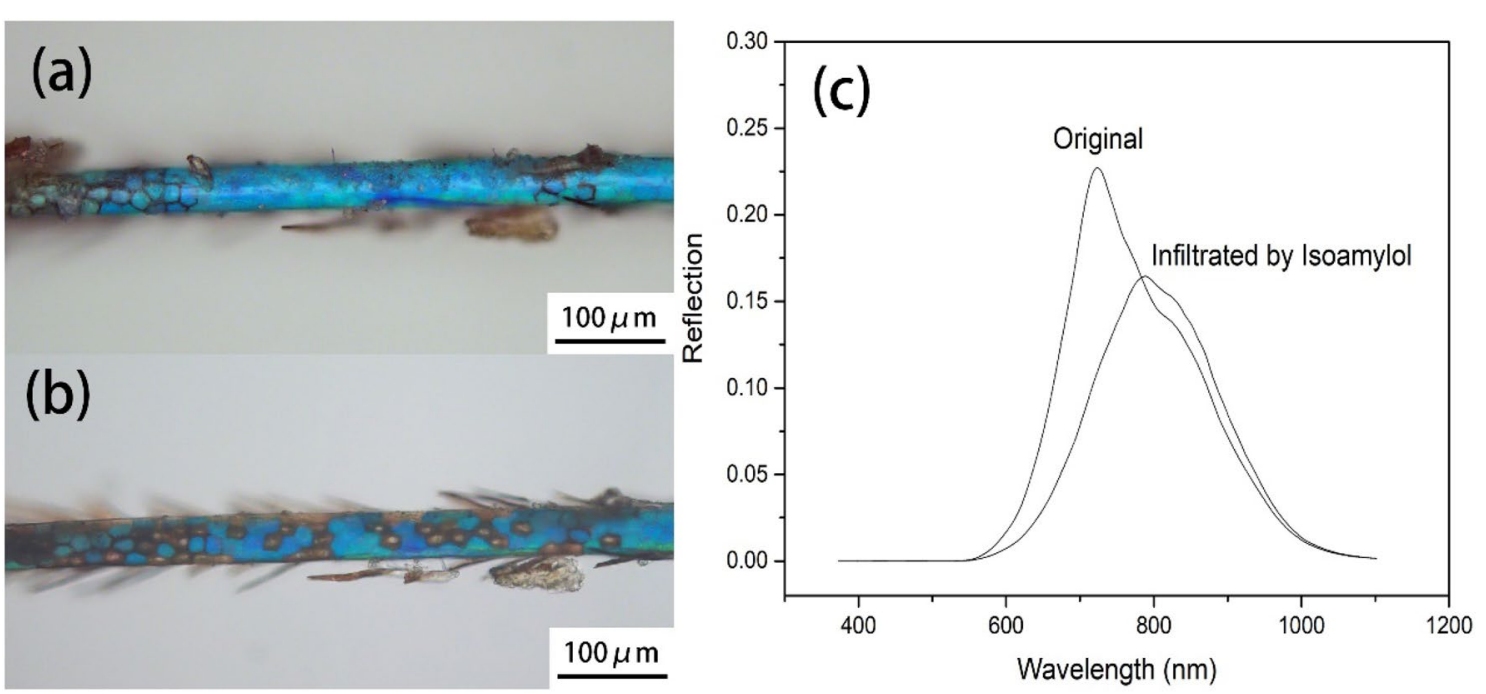

Fig. 7 Colors of the feather before and after infiltration by isoamylol; a before, $\mathbf{b}$ after and $\mathbf{c}$ the visible spectrum (LEICA metallographic microscope)

the leaf part. It also supports the conclusion that S, K and $\mathrm{Ca}$ are found in the XRF data for feathered areas (Fig. 4b). However, the reason for adding syngenite is still not clear.

According to Fig. 3, this layer is not only glue but also added black pigment. The black color can be seen through the gaps between feather fibers. Therefore, another function of this layer was to make the sensorial color of the diancui surface darker and the textures of feather fibers clearer. The bands at $1350 \mathrm{~cm}^{-1}$ and $1590 \mathrm{~cm}^{-1}$ in the Raman spectrum (Fig. 10) are the D-band and G-band of carbon [18]. This shows that the black pigment of this layer is carbon black.
Layer 3 and Layer 6: The function of Layer 3 was to bond the feather sheet (layer 1+layer 2) and support body (layer $4+$ layer $5+$ layer 6 ) together. The function of Layer 6 was to bond the diancui component on the screen. The FTIR spectra (Fig. 8b) of layer 3 and layer 6 are consistent. The bands at $3310 \mathrm{~cm}^{-1}, 1647 \mathrm{~cm}^{-1}$, $1545 \mathrm{~cm}^{-1}$, and $1448 \mathrm{~cm}^{-1}$ show that the material is protein [17].

Layer 4: This is a red layer on the top of the support body. Normally, it was called the "background color layer". Its function was to adjust the sensorial effects of color and texture of the surface because the "back side glue layer" was often transparent and the color of this layer could 

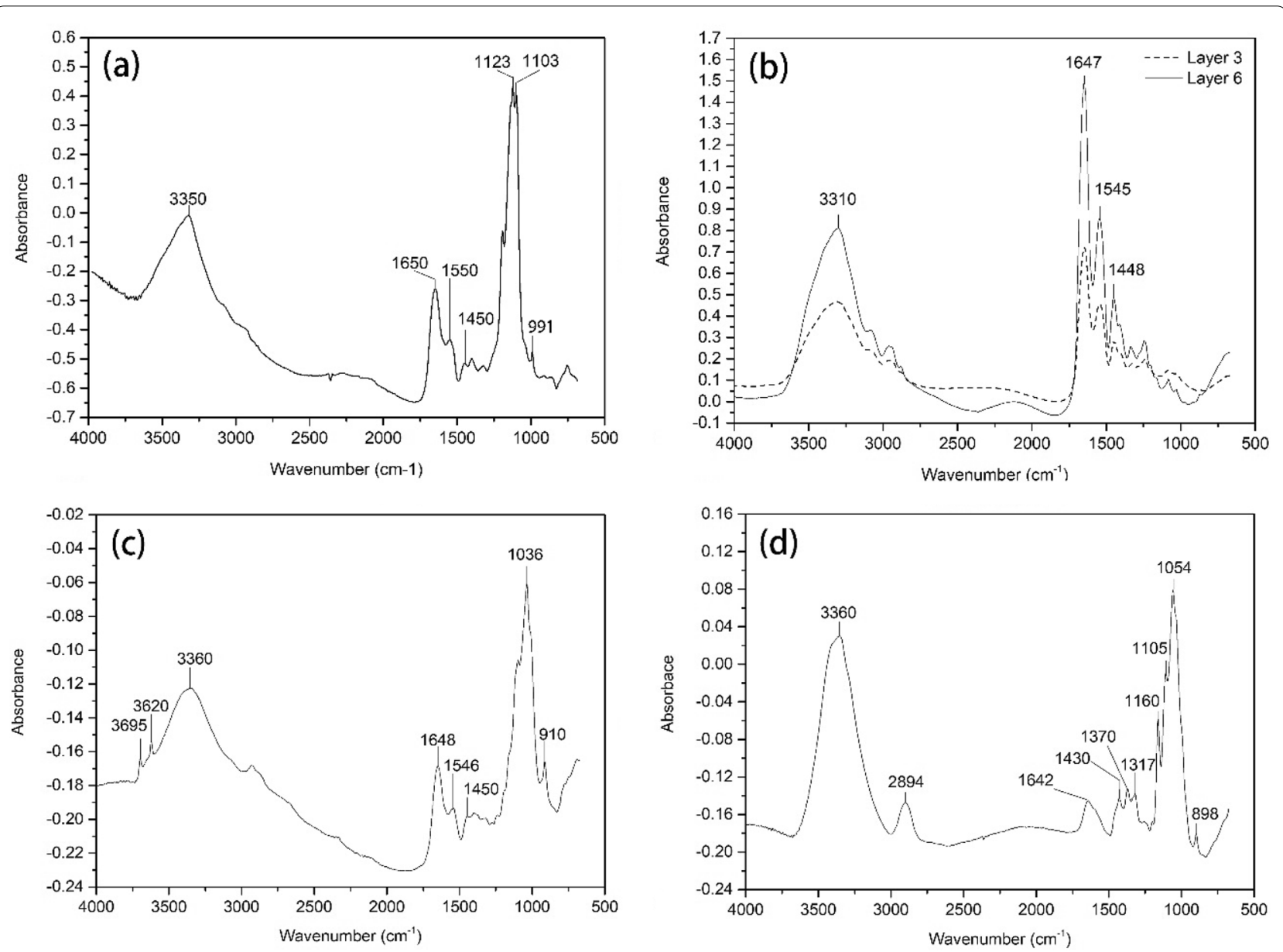

Fig. 8 FTIR spectra of layer $2(\mathbf{a})$, layers 3 and 6 (b), layer $4(\mathbf{c})$, and layer $5(\mathbf{d})$

be seen through the gaps between feather fibers. In this case, even though Layer 2 was already black, this layer was still painted red. The purpose may have been to make the color of the diancui surface look slightly warmer. $\mathrm{Fe}_{2} \mathrm{O}_{3}$ was identified in the leaf part by XRD (Fig. 9). So the red pigment may be ochre. $\mathrm{Fe}, \mathrm{Al}$ and $\mathrm{Si}$ in the XRF results (Fig. 4b) support this. The FTIR result (Fig. 8c) also supports this inference. The bands at $3695 \mathrm{~cm}^{-1}, 3620 \mathrm{~cm}^{-1}$, $1036 \mathrm{~cm}^{-1}$, and $910 \mathrm{~cm}^{-1}$ are characteristic of $\mathrm{Al}_{2} \mathrm{O}_{3}$ and $\mathrm{SiO}_{2}$ from clay [17], which are often accompanied by ochre [19]. On the other hand, the bands at $3310 \mathrm{~cm}^{-1}$, $1647 \mathrm{~cm}^{-1}, 1545 \mathrm{~cm}^{-1}$, and $1448 \mathrm{~cm}^{-1}$ showed that the materials could be protein [17].

Layer 5: The support body is the supporting structure of a diancui object and is made with metal or paper. Silver and gold are soft and easy to shape. Therefore, they were commonly used for making metal support bodies. Paper support bodies were widely used in the Qing dynasty for large jewels or for furnishings because they were much lighter than metal. The support body has rarely been studied before. In this research, layer 5 is the main part of the support body and is made of several layers of paper. In the FTIR spectrum (Fig. 8d), the bands at $3335(\mathrm{OH}$ str), 1430 ( $\mathrm{CH} 2 \mathrm{def}), 1370$ ( $\mathrm{CH}$ def), 1317 ( $\mathrm{OH}$ def), 1160, 1105, 1054 (C-O str of $\mathrm{COH} / \mathrm{C}-\mathrm{O}-\mathrm{C}), 898$ (Ring semi-circle str) are consistent with cellulose of paper [20]. Figure 11 shows the microscope structure of paper fibers. Observed by a biological microscope, the fibers look blue or brown after dying by Herzberg reagent. The shape of the fibers is straight with cuspate ends. Parenchymatous cells, sclereids and ducts could be identified. These show that the paper was made of bamboo [21]. A stick was sandwiched into the paper layers as a skeleton to make the support body stronger. The main material of this stick is copper, according to the XRF results (Fig. 4c).

\section{Violet area}

On this screen, the stones, beaks and wings of the birds were made of violet kingfisher feathers. In contrast to the light blue area, Fig. 12 shows that the back glue layer of 


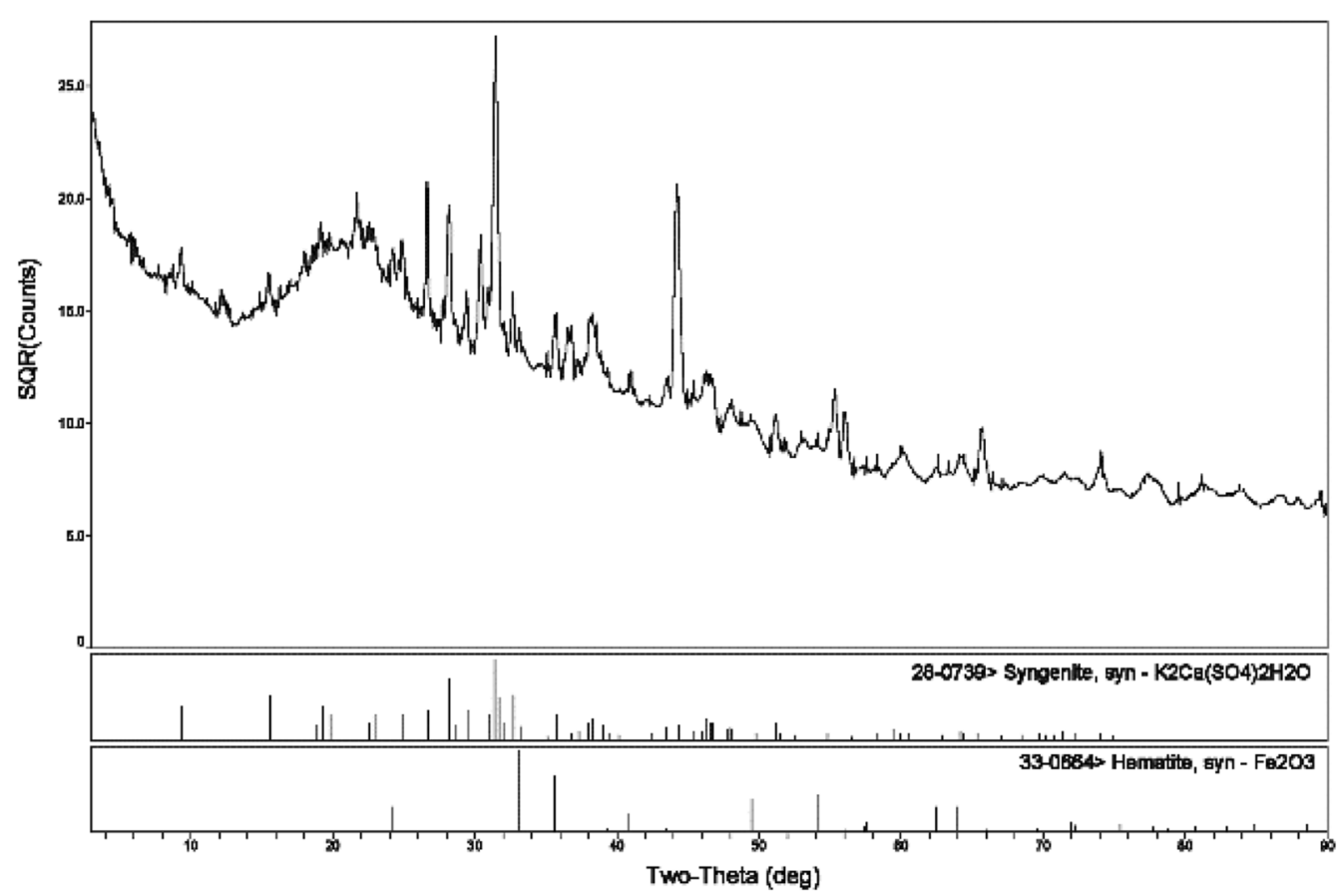

Fig. 9 XRD spectrum of the leaf pattern

the violet feather was transparent, and the background color layer was red. This design made the sensorial color of the diancui surface brighter. An interesting discovery was that the feathers of bird beaks (Fig. 12a) were sparser than those of other parts (Fig. 12b), so the colors of the beak areas look redder and close to rosy. Obviously, this was not an accident. This discovery means that ancient craftsmen changed the gaps between feather fibers to adjust the overall color. The XRF results show that the main elements of the red layer are $\mathrm{Fe}, \mathrm{Al}$ and $\mathrm{Si}$, so the red pigment may be ochre. Further analysis was not carried out because sampling was not allowed.

\section{Ground area}

The ground area had been damaged by pests. Layers under the feathers can be seen in some cracked parts. As shown in Figs. 13, four layers could be found in the cracked area (a) and the cross-section image of a fragment sample (b).

Layer 1 comprised a kind of dark feather with irisation. The microstructure of the feather fiber (Fig. 14a) was bamboo-like. This special structure is similar to the barbule of a peacock feather, which has a large number of individual barbule segments, and each segment consists of a round curved indentation [22, 23]. This feature also matches the modern peacock feather (Fig. 14b) well. The difference is that the feather of the screen is flatter than

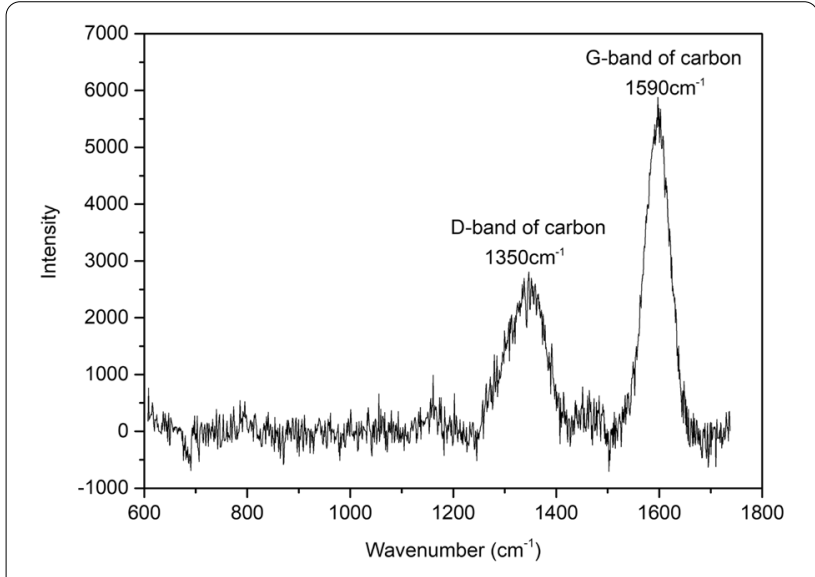

Fig. 10 Raman spectrum of layer 2

the modern feather. This means that the peacock feather on the screen may have been scraped.

Layer 2 may be the back glue layer and bonding layer combined. It was transparent. Therefore, the background color layer under this layer could be seen. The appearance and FTIR spectrum of this layer were the same as those of layers 3 and 6 of the light blue area. The material could be protein.

Layer 3 was the background color layer. Ag can be found in this layer by SEM-EDS mapping (Fig. 15b). Therefore, this layer should be silver foil used to enhance 

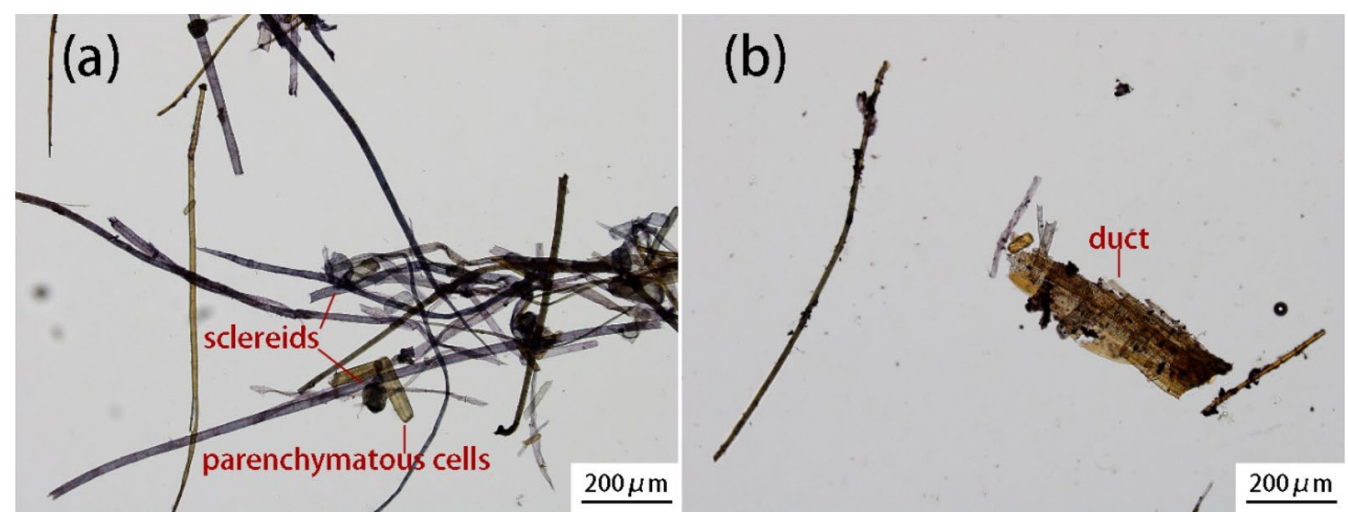

Fig. 11 Biological microscope image of paper materials in layer 5 (Olympus biological microscope). Fibers, parenchymatous cells, sclereids (a) and ducts (b) were found
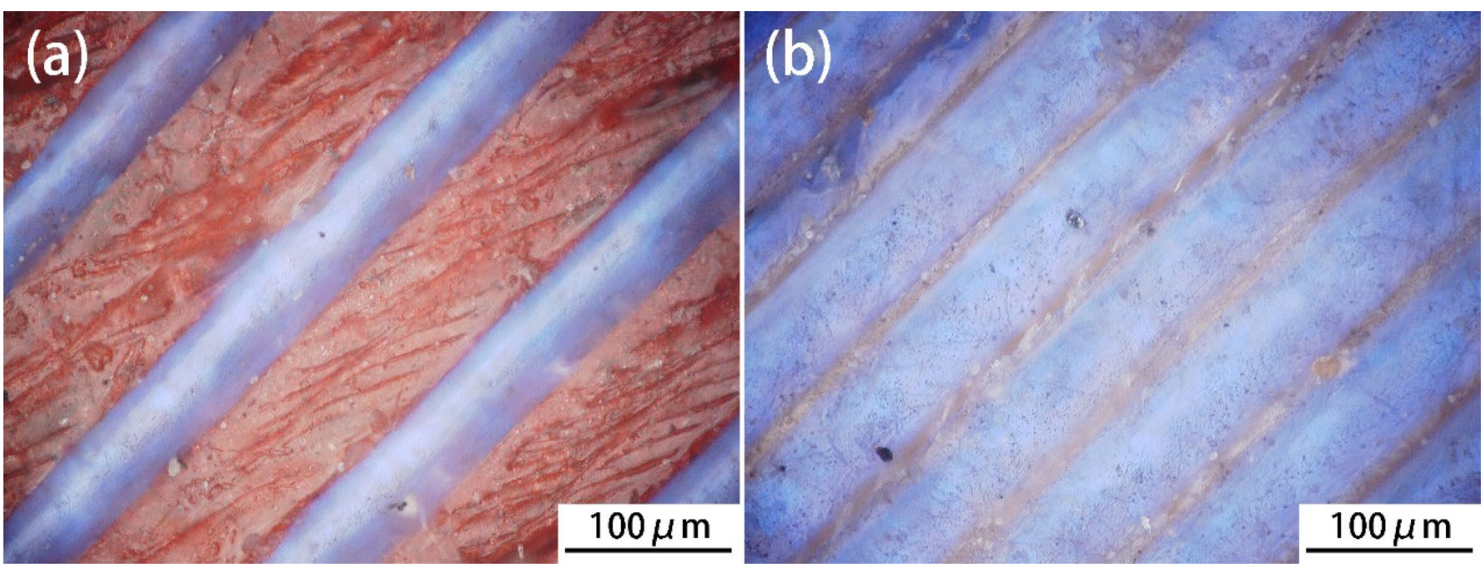

Fig. 12 Microscopic image of the bird beak part (a) and other part (b) (LEICA DVM5000 microscope)

the shiny and irisated effect of the feather surface appearance. The feather was pasted on the silver foil by yellow transparent protein glue, which made the foil look like gold. The technique may have been designed to disguise gold foil and save costs.

Layer 4 was used to stick the silver foil on the support body. It was common to add red pigments to glue for bonding foils in China. SEM-EDS mapping (Fig. 15c-f) showed that the main elements of this layer are $\mathrm{Fe}, \mathrm{Al}$, $\mathrm{Si}$, and $\mathrm{O}$. The FTIR spectrum and element results are almost the same as those of layer 6 of the light blue area. Therefore, this layer could be a mixture of ochre and protein glue. An additional structure was found in the SEM image (Fig. 15a) under this layer. They might be due to the paper fiber from the support body.

\section{Tree trunk area}

Figure 16a shows that the surface of the tree trunk area was made of a kind of brown down feather because the barbs are thin and without hooks and the barbules are thin and long. Further analysis for the identification of species was not carried out because sampling was not allowed.

Unlike other areas, a thick white layer under the feather was found at the damaged position (Fig. 16b). The purpose of this layer was to create a raised shape similar to that of a real tree trunk. The white material was identified as $\mathrm{CaCO}_{3}$, according to the characteristic bands at $1440 \mathrm{~cm}^{-1}$ and $880 \mathrm{~cm}^{-1}$ of the FTIR spectrum (Fig. 17) [17]. The strong signal for Ca in the XRF data also supported this finding.

\section{Conclusions}

Decoration with feathers was a universal phenomenon in human history. In this academic subject, Chinese tradition plays an inescapable role. However, some key historical details are still not clear. The hanging screen 


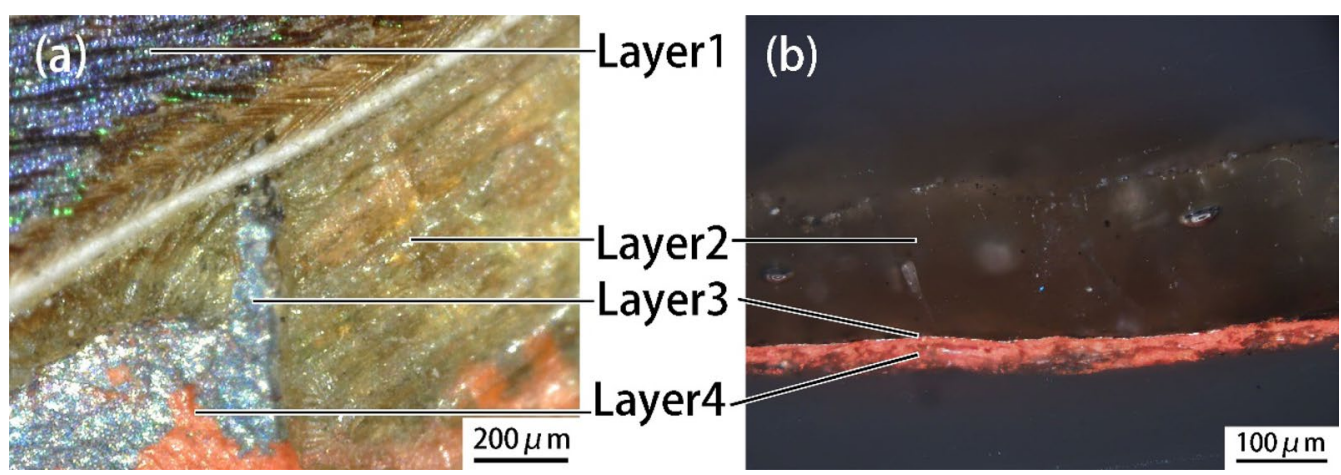

Fig. 13 Four layers were found in the cracked area (a) and cross section of a fragment (b) (LEICA DVM5000 microscope)
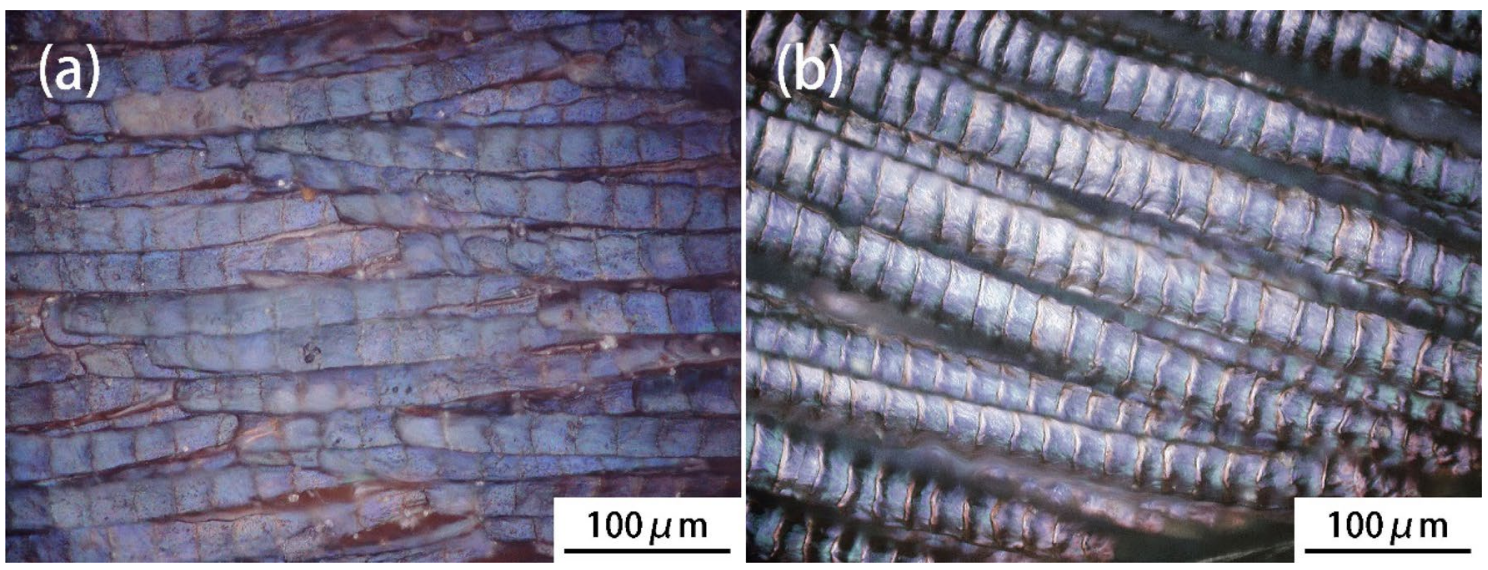

Fig. 14 Microstructures of the feathers of the ground area (a) and a modern peacock (b) (LEICA DVM5000 microscope)

investigated in this paper is a typical imperial feather decoration artwork for the seventeenth to eighteenth century in China. The research results provided important clues for better understanding the complex and ancient diancui techniques and for solving the following questions:

1. Even though only two kinds of kingfisher feathers were used, how did ancient craftsmen adjust the color and texture of the finishing surface to reach such a rich and vivid decorative effect?

The use of background color was one of the main ways to adjust the sensorial color and texture of diancui objects. In this hanging screen, a double layer of background color (black and red) was used to make the light blue feather look darker and warmer and the texture clearer. A red background color layer was used to make violet feathers look brighter. Adjusting gaps between feather fibers was another main method. The feathers of the bird beaks on the screen are sparser than those of other parts, so the color of beak looks redder and close to rosy.

2. What materials and technique were used in the support and adhesive parts of diancui objects? These lie under the feather layer and are hard to observe directly.

According to investigations on modern diancui craftsmen, there were normally two adhesive layers: a back-side glue layer and a bonding layer. The function of the back side glue layer was to bond feather fibers together to a feather sheet. Therefore, cutting and pasting small feathers would be much easier. The bonding layer bonded the feather sheet and support body together. The analytical results for the screen supported this interpretation well. Additionally, for the light blue feather, carbon black pigment was added to the 


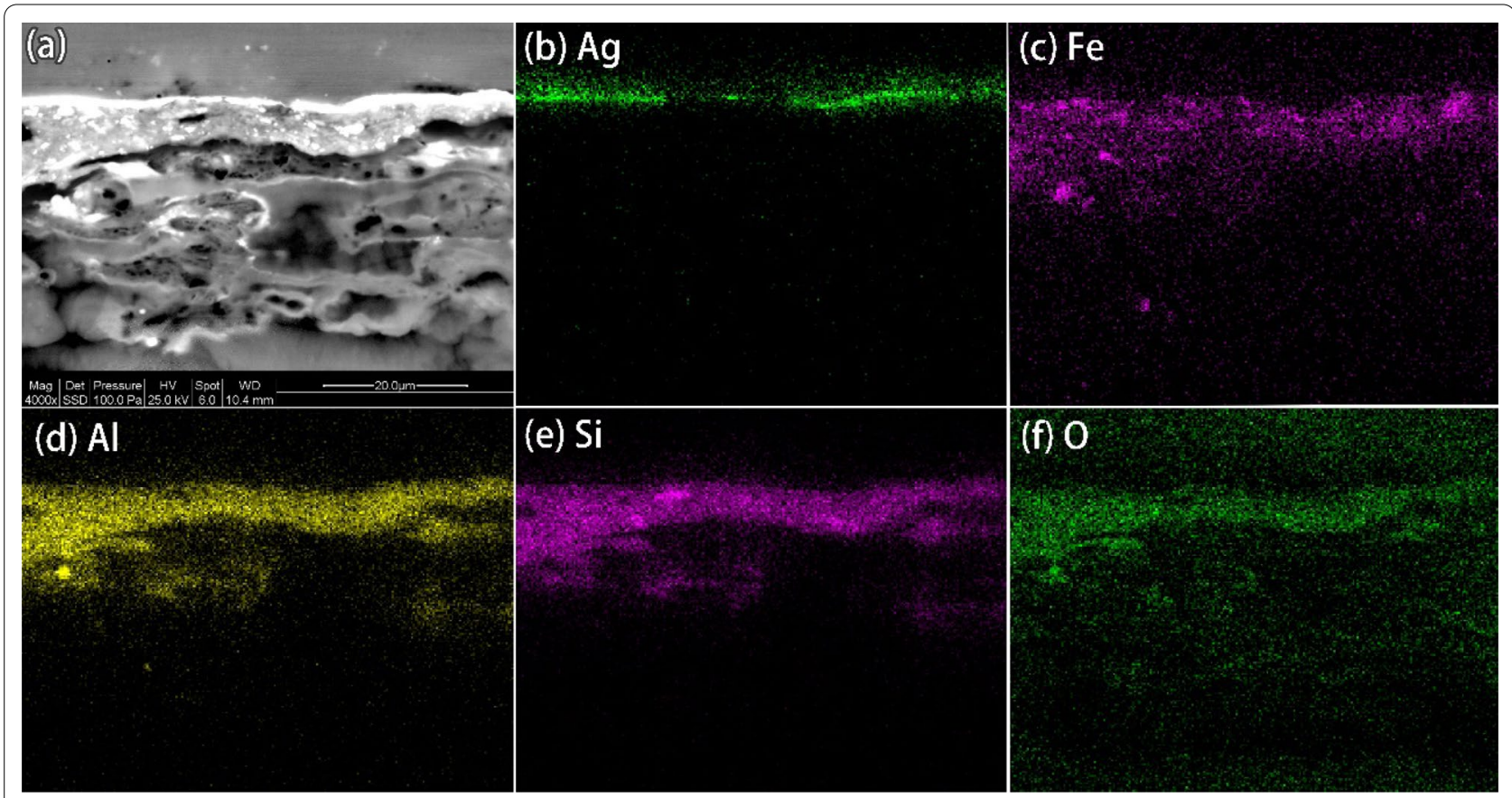

Fig. 15 SEM-EDS element mapping of Layers 3 and 4 (FEl Quanta600 SEM and EDAX Genesis EDS)
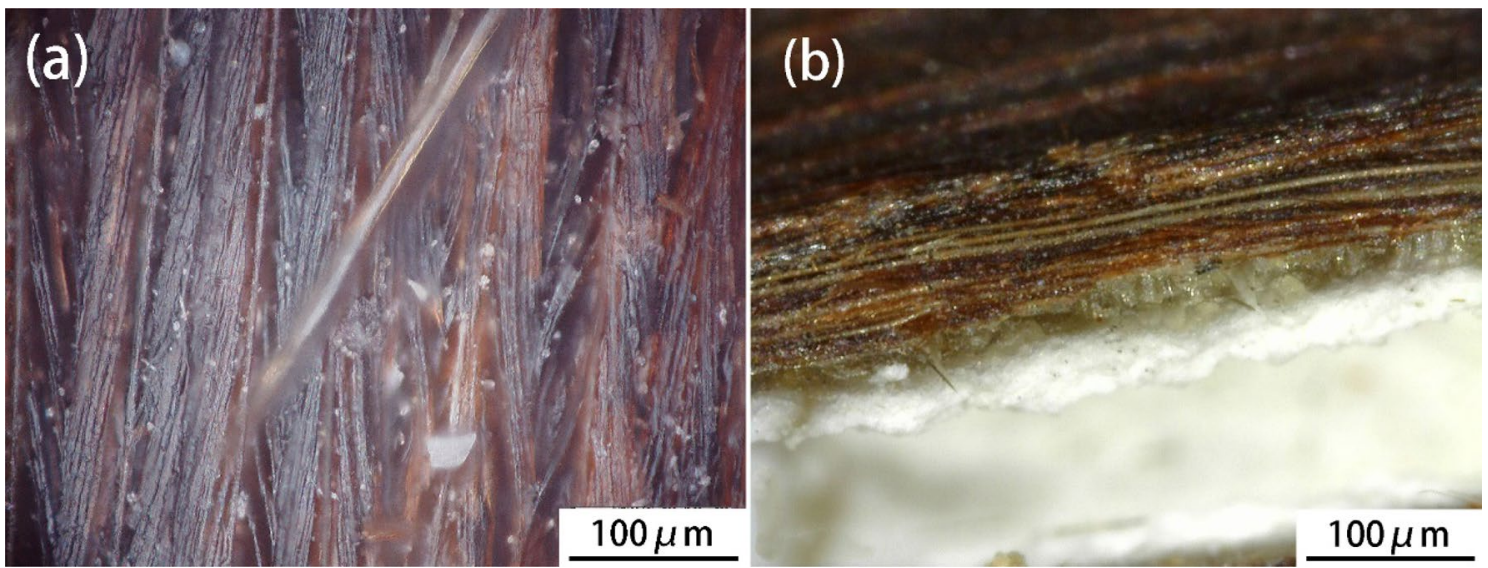

Fig. 16 Brown down feather on the surface (a) and the white thick layer under the feather (b) (LEICA DVM5000 microscope)

back-side glue layer and used to adjust color and texture in addition to the background color layer.

The support body of this screen was made of multiple layers of bamboo paper. Protein glue was used for bonding paper together. A copper stick was sandwiched in the paper layers to strengthen the body. The purpose of this design might be weight reduction for large diancui objects.
3. What other feathers were used along with kingfisher feathers? Were the techniques the same as those used with kingfisher feathers?

Peacock feathers were used in the ground area of the screen. The main structure of this area is similar to that of the diancui area. The difference is mainly in the background color layer. The material of the background color layer is silver foil without pigment, and this was used to enhance the shiny and irisated appearance of the feather surface. Interestingly, the feather was pasted on the silver 


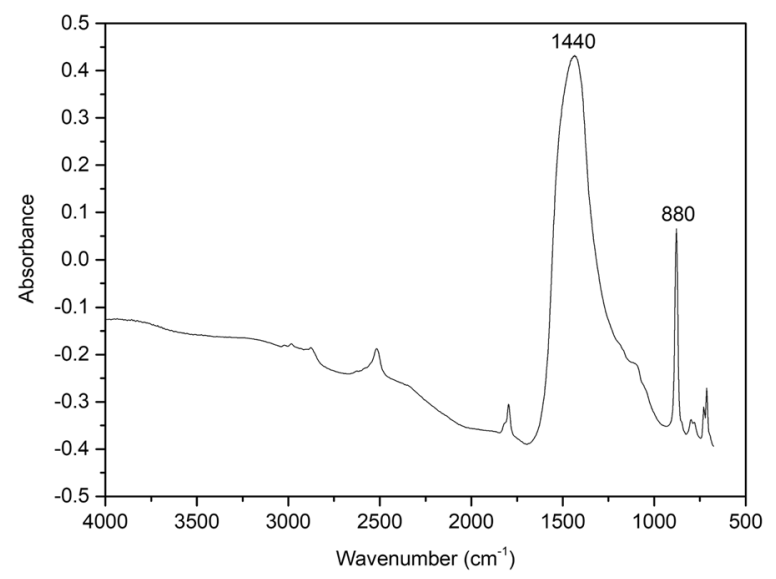

Fig. 17 FTIR spectrum of the white layer

foil with yellow transparent protein glue, which made the foil look like gold. This technique may be a design used to simulate gold foil to save costs.

A kind of brown down feather was used in the trunk area of the screen. The layer under these feathers is different from other areas. A raised shape was made with a thick layer of $\mathrm{CaCO}_{3}$ to imitate the real tree trunk.

\section{Acknowledgements}

Thanks are given to Liu Han-wen, Kang Bao-qiang, Li Yuan, Duan Pei-quan, Li Guang-hua. They helped us perform testing with Raman spectroscopy, XRD, SEM, XRF and pigment analysis. This research could not have been completed without their help.

\section{Authors' contributions}

AG performed most of the analytical work and was a major contributor in writing the manuscript. NW observed the microstructures of various bird feathers by optical microscopy and found their characteristics. YJK was the conservator of the hanging screen. She provided us with the opportunity to study it. JYH performed the in situ observation of the hanging screen by video microscopy. GL provided analysis and discussion of the structural color of kingfisher feathers. YL introduced information about the ancient craft of diancui. All authors read and approved the final manuscript.

\section{Funding}

This research was supported by the National Key R\&D Program of China, No. 2019YFC1520300.

\section{Availability of data and materials}

The datasets used and/or analyzed during the current study are available from the corresponding author upon reasonable request.

\section{Declarations}

\section{Competing interests}

The authors declare that they have no competing interests.

\section{Author details}

${ }^{1}$ Department of Conservation Science and Technology, The Palace Museum, 4 Jingshan Qianjie, Beijing 100009, China. ${ }^{2}$ Key Laboratory of Calligraphy and Paintings Conservation, Ministry of Culture and Tourism, Beijing, China.
Received: 4 March 2021 Accepted: 23 June 2021

Published online: 09 July 2021

\section{References}

1. Russo A, Wolf G, Fane D, Kunsthistorisches Institut in Florenz (eds) (2015) Images take flight: feather art in Mexico and Europe 1400-1700. Hirmer, München

2. Doughty RW. Feather fashions and bird preservation: a study in nature protection. Berkeley: University of California Press; 1975.

3. Reina RE, Kensinger KM, editors. The gift of birds: featherwork of native South American peoples. Philadelphia: The University Museum; 1991.

4. Milburn. Featherwork in early and medieval China. J Am Orient Soc. 2020;140:549.

5. Zhu Z, Tan P, Yang J, Ge H, Liu L. Mass spectrometric identification of adhesive utilized in a Tian-tsui Tiara of the mid-Qing Dynasty (1776-1839 CE) in the Collection of the Tang Clan Folk Museum. Stud Conserv. 2019;64:187-92.

6. Jackson B. Kingfisher blue: treasures of an ancient Chinese art. Berkeley: Ten Speed Press; 2001.

7. Paulson M. Visible effects of adhesive and pressure on color in kingfisher feathers. Los Angeles: UCLA; 2018.

8. University of Oxford. Chinese hairpins: "Rhapsody in Blue". Rethinking Pitt-Rivers: analyzing the activities of a nineteenth-century collector. In: Pitt Rivers Museum; 2013. http://web.prm.ox.ac.uk/rpr/index.php/objectbiography-index/1-prmcollection/290-chinese-hairpins/. Accessed 20 Feb 2021.

9. National Museums Scotland Kingfisher headdress. https://www.nms.ac uk/explore-our-collections/stories/world-cultures/kingfisher-headdress/. Accessed 20 Feb 2021.

10. Chase ES, Maccarthy B. Rhapsody in blue: kingfisher feather cloisonné in the Arthur M. Sackkler Gallery. AIC. Textile Specialty Group; 2002, p. 45-55.

11. Chandler AC (1916) A study of the structure of feathers, with reference to their taxonomic significance, by Asa C. Chandler. https://doi.org/10.5962/ bhl.title.15062

12. Davies A. Micromorphology of feathers using the scanning electron microscope. J Forensic Sci Soc. 1970;10:165-74.

13. Robertson J, Harkin C, Govan J. The identification of bird feathers. scheme for feather examination.J Forensic Sci Soc. 1984:24:85-98.

14. Lee E, Bae H, Jeon D-J, Ji S, Yeo J-S, Kim J. Microstructures in blue feathers of the common kingfisher. Proc Natl Inst Ecol Republic of Korea. 2021;2:21-5.

15. Stavenga DG, Tinbergen J, Leertouwer HL, Wilts BD. Kingfisher featherscolouration by pigments, spongy nanostructures and thin films. J Exp Biol. 2011:214:3960-7.

16. Zhang Q, Hao LV, Zhao Q, Wang X. The color analysis of peacock feather. Spectrosc Spectr Anal. 2013;33:632-5.

17. Derrick MR, Stulik D, Landry JM. Infrared spectroscopy in conservation science. Los Angeles: Getty Conservation Institute; 1999.

18. Reich S, Thomsen C. Raman spectroscopy of graphite. Philos Trans R Soc Lond Ser A. 2004;362:2271-88.

19. Gettens RJ, Stout GL. Painting materials: a short encyclopaedia. New York: Dover Publications; 1966.

20. Larkin P. Infrared and raman spectroscopy: principles and spectral interpretation. Boston: Elsevier; 2011

21. Wang J. Papermaking raw materials of china an atlas of micrographs and the characteristics of fibers. Beijing: China Light Industry Press; 1999.

22. Jiang $Y$, Wang $R$, Feng $L$, Zhang $D$. Mechanochromic response of the barbules in peacock tail feather. Opt Mater. 2018;75:74-8.

23. Burgess SC, King A, Hyde R. An analysis of optimal structural features in the peacock tail feather. Opt Laser Technol. 2006;38:329-34.

\section{Publisher's Note}

Springer Nature remains neutral with regard to jurisdictional claims in published maps and institutional affiliations. 